\title{
Diospyros Kaki Leaves Decoction Phytochemical Characterization and Bioactivities Evaluation: LC-MS-Qtof Identification, Antioxidant Activity, Enzyme Inhibition and Cytotoxicity Toward HepG2 and Mcf- 7 Cell Lines
}

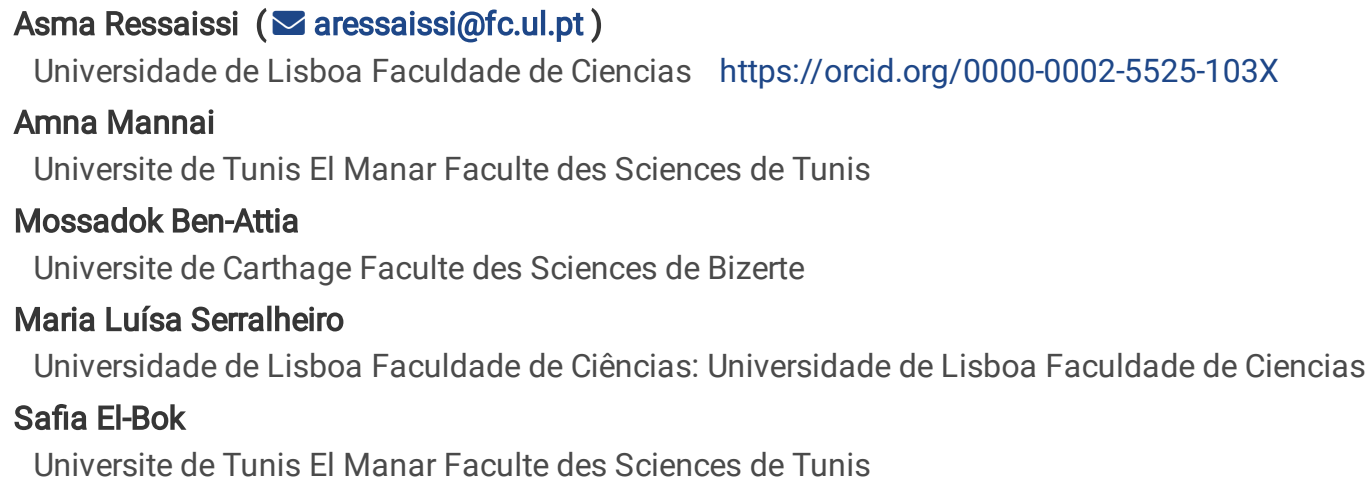




\section{Abstract}

Diospyros kaki known as Persimmon has played an important role in Chinese medicine, and its leaves are used in pharmaceuticals, cosmetics, and beverages due to their biological properties. The aim of this study was to evaluate chemical composition, antioxidant activity, enzyme inhibition. The main compounds of Diospyros kaki leaves decoctions were identified using high-resolution liquid chromatography - high-resolution tandem mass spectrometry (LC-HRMS-MS) interfaced with a Quadrupole Time-of-Flight (Q-tof). The obtained results showed that the aqueous extract had a high content of total phenolsand flavonoids and showed strong antioxidant activity $\left(\mathrm{EC}_{50}\right.$ between $3.79 \pm 0.19$ and $\left.12.05 \pm 0.11 \mu \mathrm{g} / \mathrm{mL}\right)$. In addition, these extracts were able to inhibit3-hydroxy-3-methylglutaril-CoA (HMG-CoA) reductase and acetylcholinesterase ( $\mathrm{IC}_{50}$ ranging from $58.35 \pm 0.69$ to $210.21 \pm 28.9 \mu \mathrm{g} / \mathrm{mL}$ ). The cytotoxicity against human liver cells HepG2 and breast MCF7 cell lines was also evaluated. No cytotoxicity to HepG2 and MCF7 cells was detected. These results indicate that Diospyros kaki leaves could be considered as attractive source of health-promoting ingredients and a promising plant for the development of new functional foods and pharmaceutical products.

\section{Introduction}

Persimmon (Diospyros kaki L.), which originated from China, belongs to the family of Ebenaceae and has been cultivated over centuries in Eastern Asia. The fruit of persimmon is eaten fresh or dry, whereas the leaf is generally used for tea due to their functional properties [1]. Persimmon (Diospyros kaki L.) leaves have played an important role in Chinese medicine [2, 3].

Recently, plant extracts have been the subject of several research in order to obtain bioactive compounds such polyphenols which are known to have pharmacological activities [4]. Persimmon leaves extracts have been shown to possess a wide range of pharmacological activities, including antioxidant, anti-acetylcholinesterase and anti-diabetic activities, and they have been used to treat ischemic stroke, angina, internal hemorrhage, hypertension, atherosclerosis and some infectious diseases $[5,6,7,8,9,10]$. However, these biological activities have been primarily attributed to their tannins, flavonoids, and phenolic acids. Particularly, flavonoids in persimmon leaf including kaempferol, quercetin, and catechin demonstrated a robust antioxidant activity and an ability to regulate blood pressure $[9,11]$. Moreover, quercetin reveals anti-cancer, anti-allergic and anti-inflammatory activities [12, 13, 14, 15], whereas kaempferol shows the preventive activity against Alzheimer's disease [16].

Alzheimer's disease (AD), which is a progressive neurodegenerative disorder, is associated with the loss of cholinergic neurons [17]. Nowadays, several treatments are used against AD namely acetylcholinesterase inhibitors, a key enzyme in the cholinergic nervous system. In addition to the commercial drugs, some plants rich in phenolic compounds, were reported to have AChE inhibitory activity [18, $19,20,21]$.

Hypercholesterolemia, characterized by the presence of high levels of cholesterol in the blood caused by high intake of cholesterol, saturated fats, and excessive calories or by genetic factors [22], can lead to other diseases such as obesity, diabetes and cancer [23; 24].Cholesterol turn-over and homeostasis in the body involve many pathways including the inhibition of the rate-limiting enzyme 3hydroxy-3 La -methylglutaryl-coenzyme A (HMG-CoA) reductase [25] Currently, HMGR inhibitors are commonly used as efficient cholesterol-lowering drugs. In addition to statins, several phenolic compounds could fit within the active site of the enzyme indicating that this may be one of the procedures by which cholesterol biosynthesis is inhibited $[26 ; 27,28,29,30]$.

Antioxidant activity in cells is also another important biological activity, as it prevents ROS formation and contributes to the reduction of inflammatory processes which are the basis of several diseases such as neurodegenerative diseases, cardiovascular disorders and cancer [31, 32, 33]. It has been demonstrated that oxidative stress causes changes in gene expression, cell proliferation, and apoptosis and plays a significant role in tumour initiation and progression [33]. Increased proliferation, reduced apoptosis, and increased survival are the main characteristics of cancer cells [34]. One of the ways to treat cancer is the inhibition of the proliferation cancer cell. The dietary consumption of antioxidant from herbs is associated with anticancer activity which has been suggested by epidemiology and considered to promote cancer reduction [35].

The aim of this study was the identification of the phenolic compounds present Diospyros kaki $L$ leaves and the evaluation of their antioxidant activity as well as enzyme inhibitory activity over AChE and HMGR. The cytotoxicity of the obtained extracts against human liver and breast cancer cells was also evaluated.

\section{Results And Discussion}




\subsection{Quantification of bioactive compounds}

Phenolic compounds are considered to be the most important antioxidants and are widely distributed among various plant species. The presence of the phenolic compounds could contribute to the protective properties and therefore it is quite important to assess the total phenolic content in the extracts tested. The content of phenolic acids is reported in $\mu \mathrm{g}$ of gallic acid equivalents (GAE)/mg of extract. The total phenols content in the different varieties was between $325,19 \pm 7,4$ and $490,91 \pm 5,1 \mu \mathrm{g}$ of GAE/mg extract. Statistical analyses showed that, at 95\%confidence level, the extracts were statistically different (Table1). Among the studied varieties, Rojo B showed the highest amount of total phenols with a value of $490,91 \pm 5,1 \mu \mathrm{g}$ of $\mathrm{GAE} / \mathrm{mg}$ extract, whereas the Jiro variety had the lowest total phenols content $(325,19 \mu \mathrm{g}$ of GAE/mg extract). Lower values have been reported in the other scientific literature. For instance, Esteban-Muñoz et al., [11], found that the astringent persimmons (Rojo B) and the non-astringent persimmons (Triumph) have lower concentrations of total phenolic with values of $380.786 \mathrm{and} 84.568 \mu \mathrm{g}$ of $\mathrm{GAE} / \mathrm{g}$ respectively.

The flavonoid content in the different varieties of persimmon leaves were calculated using the standard curve for catechin. It has been observed that the flavonoid content was $126.1 \pm 6.3,223.1 \pm 4.4$ and $293.2 \pm 4.8 \mu \mathrm{g} \mathrm{CE} / \mathrm{mg}$ of extract for respectively Rojo B, Triumph and Jiro varieties.

The Rojo B variety has the highest flavonoids content at $293.25 \pm 4.8 \mu \mathrm{g}$ of $\mathrm{CE} / \mathrm{mg}$ of extract followed by the Triumph variety. However, the Jiro variety had the lowest flavonoids content compared to the others with $126.06 \pm 6.3 \mu \mathrm{g}$ of $\mathrm{CE} / \mathrm{mg}$ of extract (Table 1). Statistical analysis showed that, at $95 \%$ confidence level, the flavonoid content in the three varieties was statistically different. Comparatively, a study conducted by Sun et al. [36], demonstrated that Persimmon (D. kaki L. folium) leaves possesses considerable amounts of flavonoids (192 $\mu \mathrm{g}$ of Catechin equivalent / mg of extract). [36].

Table1. Total phenols and total flavonoids contents in persimmon leaves extracts of three different varieties collected in Tunisia.

\begin{tabular}{|lll|}
\hline Variety & Total phenols ( $\mu \mathrm{g} \mathrm{GAE} / \mathrm{mg}$ extract). & Total flavonoids ( $\mu \mathrm{g} \mathrm{CE} / \mathrm{mg}$ extract). \\
\hline Triumph & $359,77 \pm 6,42^{\mathrm{a}}$ & $223,05 \pm 4,498^{\mathrm{a}}$ \\
\hline Jiro & $325,19 \pm 7,48^{\mathrm{b}}$ & $126,063 \pm 6,377^{\mathrm{b}}$ \\
\hline Rojo B & $490,91 \pm 5,19^{\mathrm{C}}$ & $293,252 \pm 4,894^{\mathrm{c}}$ \\
\hline
\end{tabular}

a, b, c Different letters mean significantly different at 0.05

\subsection{LC-MS-Qtof analysis}

Persimmon leaves are interesting for their bioactive compounds that may exert beneficial effects on human health [2]. The phenolic fraction of the three varieties of Persimmon leaves was analyzed by LC-MS/MS. Extracts were analyzed in positive and negative mode but the identification was carried out only in negative mode where a higher number of compounds was found, also with higher intensity. Chromatograms of the three persimmon cultivars are shown in Figure 1. In total, 28 polyphenols were identified, including 1 benzoic acid, 15 flavonols, 7 flavones, 3isoflavonoides, 1 flavanones and 1 methoxyphenols (Table 2). Qualitative polyphenol screening of persimmon extracts revealed variation in phenolic constituents with regards to type of cultivars whereby the differences was detected in the presence or absence of fragmentation compounds as summarized in Table 2. Our results show that persimmon leaves have a complex phenolic profile that may help to explain the beneficial effects of their traditional use as a medicinal herb.

Other literature mentions the presence of simple phenolic compounds (hydroxybenzoicacids and hydroxycinnamic acids), tannins, procyanidins, flavonoids, and tyrosols [37-39, 11].

Table2: Identification of compounds in persimmon cultivars based on their spectral LC-MS characteristics in negative ion mode.

\subsection{Antioxidant activity}

Oxidative stress inside the cell may be the cause of several diseases [31,32]. The use of antioxidants to prevent the formation of 


\begin{tabular}{|c|c|c|c|c|c|c|c|c|}
\hline \multirow[t]{2}{*}{ Peak } & \multirow{2}{*}{$\begin{array}{l}\mathrm{Rt} \\
(\mathrm{min})\end{array}$} & \multirow[t]{2}{*}{ Compound (subclass) } & \multirow{2}{*}{$\begin{array}{l}\text { Molecular } \\
\text { formula }\end{array}$} & \multirow{2}{*}{$\begin{array}{l}\text { Accurate } \\
{[\mathrm{M}-\mathrm{H}]^{-} m / z} \\
(\Delta \mathrm{ppm})\end{array}$} & \multirow{2}{*}{$\begin{array}{l}\text { Fragments } \mathrm{m} / \mathrm{z}(\% \\
\text { intensities) }\end{array}$} & \multicolumn{3}{|c|}{ Availability } \\
\hline & & & & & & $\begin{array}{l}\text { Rojo } \\
\text { B }\end{array}$ & Jiro & Triumph \\
\hline 1 & 1.1 & $\begin{array}{l}\text { 8-Hydroxydaidzein } \\
\text { (Isoflavones). }\end{array}$ & $\mathrm{C}_{15} \mathrm{H}_{10} \mathrm{O}_{5}$ & $\begin{array}{l}269.0434 \\
(-3.7)\end{array}$ & $88.9824(100)$ & & & $x$ \\
\hline 1 & 1.1 & $\begin{array}{l}\text { 6,8-Di-C-methylkaempferol 3,7- } \\
\text { dimethyl ether (Flavonols) }\end{array}$ & $\mathrm{C}_{15} \mathrm{H}_{18} \mathrm{O}_{9}$ & $\begin{array}{l}341.1005 \\
(-7.62)\end{array}$ & $165.0355(100)$ & & $x$ & $x$ \\
\hline 1 & 1.1 & $\begin{array}{l}\text { 7-Hydroxy-3', } 4^{\prime}, 5,6,8- \\
\text { pentamethoxyflavone } \\
\text { (Flavones) }\end{array}$ & $\mathrm{C}_{20} \mathrm{H}_{20} \mathrm{O}_{8}$ & $\begin{array}{l}387.1038 \\
(-6.4)\end{array}$ & $\begin{array}{l}89.0192(100) \\
119.0536(64) \\
149.0397(24) \\
179.0503(42)\end{array}$ & $x$ & $x$ & $x$ \\
\hline 1 & 1.1 & $\begin{array}{l}\text { Benzoyl benzoate (Benzoic } \\
\text { acid) }\end{array}$ & $\mathrm{C}_{14} \mathrm{H}_{10} \mathrm{O}_{3}$ & $\begin{array}{l}225.0547 \\
0.44\end{array}$ & $\begin{array}{l}59.0091(100) \\
89.0192(30)\end{array}$ & $x$ & $x$ & $x$ \\
\hline 2 & 1.2 & $\begin{array}{l}\text { 5-Hydroxy-3,7,8,2',4'- } \\
\text { pentamethoxyflavone(Flavones) }\end{array}$ & $\mathrm{C}_{20} \mathrm{H}_{20} \mathrm{O}_{8}$ & $\begin{array}{l}387.1047 \\
(0.51)\end{array}$ & $\begin{array}{l}59.0085(100) \\
89.0192(84) \\
341.1023(32)\end{array}$ & & $x$ & \\
\hline 2 & 1.2 & $\begin{array}{l}\text { 5,7,8-Trihydroxyflavone 7- } \\
\text { galactoside (Flavones) }\end{array}$ & $\mathrm{C}_{21} \mathrm{H}_{20} \mathrm{O}_{10}$ & $\begin{array}{l}431.0921 \\
(-11.8)\end{array}$ & $89.9844(100)$ & & $x$ & $x$ \\
\hline 2 & 1.2 & $\begin{array}{l}\text { 7,2'-Dihydroxy-3',4'- } \\
\text { dimethoxyisoflavone 7-0- } \\
\text { glucoside (Flavones) }\end{array}$ & $\mathrm{C}_{23} \mathrm{H}_{24} \mathrm{O}_{11}$ & $\begin{array}{l}475.1173 \\
(-12.8)\end{array}$ & $\begin{array}{l}133.0090(100) ; \\
114.9983(40) 135.0244 \\
(38)\end{array}$ & & & $x$ \\
\hline 3 & $\underline{1.3}$ & $\begin{array}{l}5,2^{\prime}, 5^{\prime}-\text { Trihydroxy-3, 6,7, 4'- } \\
\text { tetramethoxyflavone 5'- } \\
\text { glucoside (Flavones) }\end{array}$ & $\stackrel{\mathrm{C}}{\mathrm{C}} \mathrm{H}_{28} \mathrm{O}_{14}$ & $\begin{array}{l}551.1310 \\
(-15.4)\end{array}$ & $\begin{array}{l}95.9487(100) \\
78.9517(60)\end{array}$ & & $x$ & \\
\hline 3 & $\underline{1.3}$ & $\begin{array}{l}\text { Kaempferol 3-rhamnoside } \\
\text { (Flavonols) }\end{array}$ & $\mathrm{C}_{21} \mathrm{H}_{20} \mathrm{O}_{10}$ & $\begin{array}{l}431.0924 \\
(-13.91)\end{array}$ & $88.9827(100)$ & & $x$ & $x$ \\
\hline 4 & $\underline{1.5}$ & $\begin{array}{l}\text { Quercetagetin 3, 5, 6, 7,3'- } \\
\text { pentamethyl ether(Flavonols) }\end{array}$ & $\begin{array}{l}\mathrm{C}_{20} \mathrm{H}_{20} \mathrm{O} \\
8\end{array}$ & $\begin{array}{l}387.1085 \\
(2.0)\end{array}$ & $\begin{array}{l}89.0190(100) ; \\
341.0999(58) \\
179.0502(41) ; \\
113.0196(20)\end{array}$ & & $x$ & $x$ \\
\hline 5 & 5.1 & (+)-Catechin(Flavonols) & $\mathrm{C}_{15} \mathrm{H}_{14} \mathrm{O}_{6}$ & $\begin{array}{l}289.0635 \\
(-24.5)\end{array}$ & $\begin{array}{l}109.0242(100) \\
123.0400(80) \\
203.0649(57) \\
151.0353(40)\end{array}$ & $x$ & $x$ & $x$ \\
\hline 5 & $\underline{5.1}$ & $\begin{array}{l}\text { Kaempferol 3-0-xylosyl- } \\
\text { glucoside (Flavonols) }\end{array}$ & $\mathrm{C}_{26} \mathrm{H}_{28} \mathrm{O}_{15}$ & $\begin{array}{l}579.1339 \\
(0.86)\end{array}$ & $\begin{array}{l}289.0640(100) \\
245.0750(11)\end{array}$ & $x$ & $x$ & $x$ \\
\hline 6 & $\underline{5.2}$ & $\begin{array}{l}\text { 3,5,8-Trimethoxy-6,7:3',4'- } \\
\text { bis(methylenedioxy) flavones } \\
\text { (Flavones) }\end{array}$ & $\mathrm{C}_{20} \mathrm{H}_{16} \mathrm{O}_{9}$ & $\begin{array}{l}399.0827 \\
(29.3)\end{array}$ & $\begin{array}{l}191.0287(100) \\
152.0162(13)\end{array}$ & $x$ & $x$ & $x$ \\
\hline 7 & $\underline{5.4}$ & $\begin{array}{l}5,3^{\prime}, 5^{\prime}-\text { Trihydroxy-3, } 6,7,8,4^{\prime}- \\
\text { pentamethoxyflavone } \\
\text { (Flavones ) }\end{array}$ & $\mathrm{C}_{20} \mathrm{H}_{20} \mathrm{O}_{10}$ & $\begin{array}{l}419.1085 \\
(26.9)\end{array}$ & $\begin{array}{l}89.0190(100) \\
141.0141(82) \\
71.0084(74) ; 119.0301 \\
(57)\end{array}$ & $x$ & & - \\
\hline 7 & 5.4 & $\begin{array}{l}\text { Daidzein 6"-Oacetate } \\
\text { (Isoflavonoids) }\end{array}$ & $\mathrm{C}_{23} \mathrm{H}_{22} \mathrm{O}_{10}$ & $\begin{array}{l}457.1240 \\
(24.3)\end{array}$ & $\begin{array}{l}119.0450(100) \\
163.043(83)\end{array}$ & $x$ & $x$ & $x$ \\
\hline 8 & $\underline{6.6}$ & Quercetagetin 3'-methylether 6- & $\mathrm{C}_{22} \mathrm{H}_{22} \mathrm{O}_{13}$ & 493.0869 & $315.0062(100)$ & $x$ & $x$ & $x$ \\
\hline
\end{tabular}




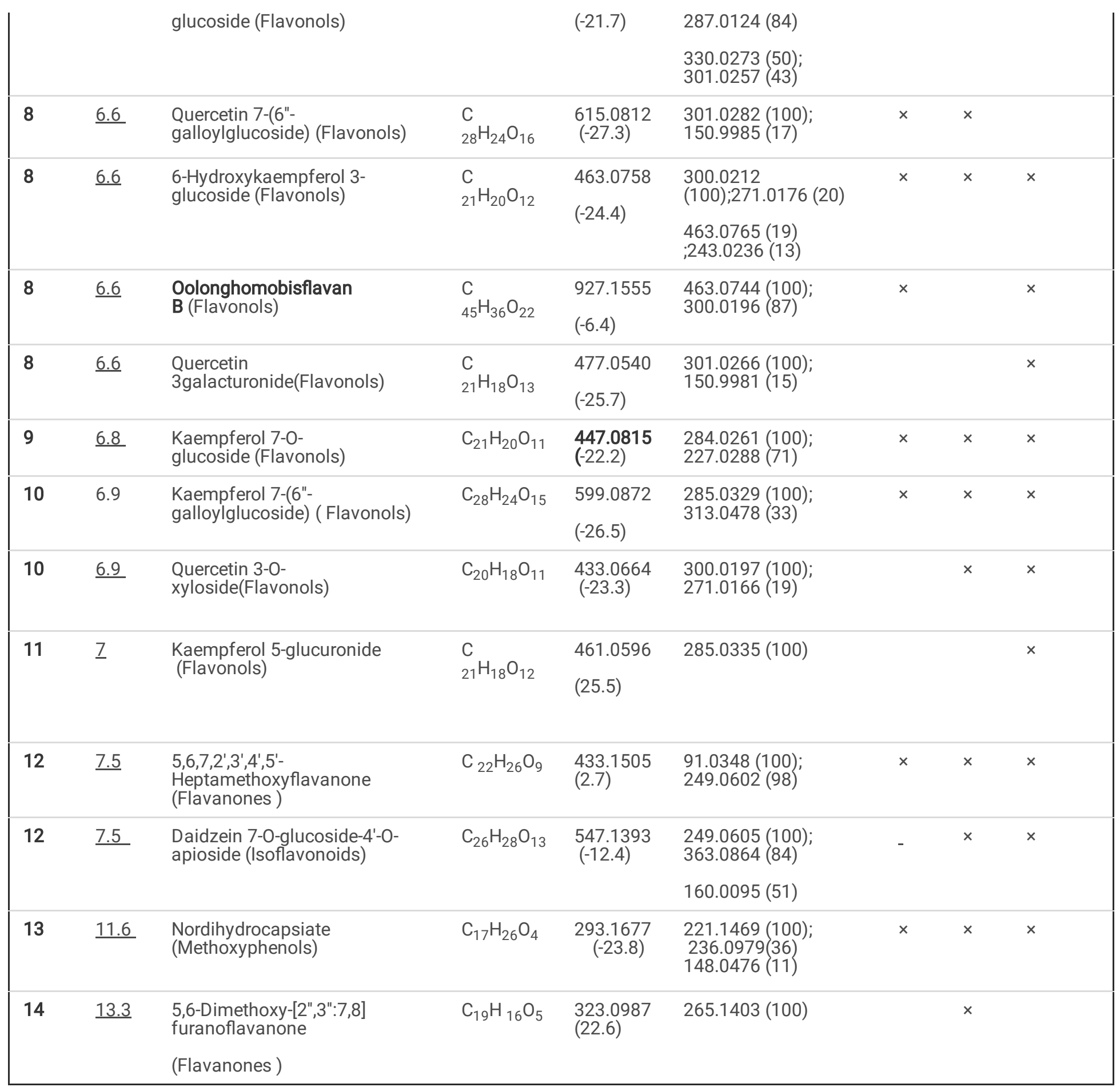

oxidative stress inside cells has been recommended [40]. The antioxidant activity of the extract of the different varieties of persimmon leaveswas evaluated by the DPPH radical scavenging assaywhich is a good in vitro model to investigate the antioxidant activity [41].

The results from the radical scavenging assays for all extracts are presented in Table 3 . The highest antioxidant activity was obtained with Rojo $B$ extract $\left(E_{50}=3.79 \pm 0.19 \mu \mathrm{g} / \mathrm{mL}\right)$. These obtained results suggest that the three varieties possess very high antioxidant activity and better than the activity of $(\mathrm{BHT})$ that has an $\mathrm{EC}_{50}$ of $25.42 \pm 1.46 \mu \mathrm{g} / \mathrm{mL}$ [21]. The statistical analysis showed a that the three varieties are significantly different at $95 \%$ confidence level $(a=0.05)$.

The observed differences in the antioxidant activity can be attributed to the structure and content of phenolic compounds [42]. In fact, the highest antioxidant activity was attributed to the extract that has higher polyphenols and flavonoids. In addition, previous descriptive structure-radical scavenging activity relationships of flavonoids demonstrated that the positions of phenolic $\mathrm{OH}$ groups could be more important for the radical scavenging activity than the number of phenolic $\mathrm{OH}$ groups $[43,44]$ and it has been shown that glycosylated 
polyphenols have a reduced ability to donate hydrogen and are less effective in the antioxidant capacity compared to their free forms as aglycones [45].

\subsection{Acetylcholinesterase inhibition}

In the present study, persimmon leaves extracts were tested to evaluate their anti-acetylcholinesterase activity. AChE inhibitor activity of extracts was found to increase dose-dependently, the results expressed as $I C_{50}(T a b l e ~ 3)$. The best inhibitory activity was exhibited by the leaf extract of variety Rojo B followed by the leaves of Triumph and Jiro varieties. For instance, the variety Rojo B had the highest inhibition with an $\mathrm{IC}_{50}$ value of $58.35 \pm 0.69 \mu \mathrm{g} / \mathrm{mL}$, while the extract from persimmon leaves of Jiro variety exhibited the lowest activity with an $\mathrm{IC}_{50}$ value of $210.21 \pm 28.9 \mu \mathrm{g} / \mathrm{mL}$. The statistical analysis showed that the anti-acetylcholinesterase activity of leaf extract from Truimph and Rojo B was not significantly different at $95 \%$ confidence level whereas Jiro leaves extract was significantly different from Truimph and Rojo B leaves extracts.

The good inhibitory activity obtained with persimmon leaf extracts could be attributed to their chemical composition which mainly contain phenolic, as well as the possible synergistic interaction between these components. In fact, several studies showed that other phenolic compounds possess the ability to fit into the active site and act as acetylcholinesterase inhibitors [19, 21, 29].

Previous studies on other diospyros species tested for their inhibitory activities found that aqueous extract of Diospyros lotus fruit exhibited a low anti-AChE activity with an $\mathrm{IC}_{50}$ value of $16.75 \pm 0.11 \mu \mathrm{g} / \mathrm{mL}$ whereas the ethanol extract of Diospyros lotus leaves had an inhibition of $23.53 \pm 2.06 \%$ for $100 \mu \mathrm{g} / \mathrm{mL}[46]$.

Table 3: Antioxidant activity and AChE inhibitory activity of three variety persimmon leaves

\begin{tabular}{|lll|}
\hline Variety & $\mathrm{DPPH}\left(\mathrm{EC}_{50} \mu \mathrm{g} / \mathrm{mL}\right)$ & $\mathrm{AChE}\left(\mathrm{IC}_{50} \mu \mathrm{g} / \mathrm{mL}\right)$ \\
\hline Triumph & $8.01 \pm 0.35^{\mathrm{a}}$ & $95.98 \pm 16.3^{\mathrm{a}}$ \\
\hline Jiro & $12.05 \pm 0.11^{\mathrm{b}}$ & $210.21 \pm 28.9^{\mathrm{b}}$ \\
\hline Rojo B & $3.79 \pm 0.19^{\mathrm{c}}$ & $58.35 \pm 0.69^{\mathrm{c}}$ \\
\hline
\end{tabular}

a, b, c Different letters mean significantly different at 0.05

\subsection{HMG-CoA reductase assay}

A reduction in cholesterol synthesis is probably the most efficient way to lower plasma cholesterol levels. Persimmon leaves aqueous extracts, for a concentration of $100 \mu \mathrm{g} / \mathrm{mL}$, showed a good inhibitory activity for HMGR(Figure2). The extracts had a percentage of inhibition of $61.44 \%, 57.35 \%$, and $46.28 \%$ for Rojo B, Jiro and Triumph varieties, respectively on HMG-CoA. The obtained results showed the ability of persimmon leaves extract to have cholesterol lowering effect by inhibiting the rate-limiting enzyme of the cholesterol biosynthesis HMG-CoA reductase. Previous study using ethanol extract of persimmon fruits on HepG2 cells showed an inhibition of HMG-CoA reductase and a decrease in cholesterol level in HepG2 cells [47]. In addition, it has been shown that the effect of phenolic acids on HepG2 cell line at a molecular level is similar to pravastatin, a drug often prescribed to inhibit HMG-CoA reductase enzyme [48].

\subsection{Cytotoxicity}

The toxicity of persimmon leaves aqueous extract was tested in the human cell lines HepG2 and MCF7, using 5 serial concentrations ranging from 0.05 to $1 \mathrm{mg} / \mathrm{mL}$ of extract (Figure 3). The obtained results showed that an increase in the concentration of the extract decreased the viability of the treated cell. The concentration of extracts that killed $50 \%$ of the cells $\left(\mathrm{IC}_{50}\right)$ was determined from the doseresponse curves (Table 1). IC $_{50}$ values for HepG2 cells were lower than those of MCF-7 cell lines for Rojo B and Triumph varieties, in contrast IC $\mathrm{I}_{50}$ values for HepG2 cells were higher than those of MCF-7 cell lines for Jiro variety. The obtained results showed that none of the tested extracts have any cytotoxic effect on HepG2 and MCF-7 cells since the $\mathrm{IC}_{50 \%}$ values were higher than the established one for 
this type of test which is $0.1 \mathrm{mg} / \mathrm{mL}$ except Hep $\mathrm{G} 2$ cells treated with Rojo B which had an IC ${ }_{50}$ in the limit of toxicity [49]. Other study of ethanolic extract of astringent persimmons on HepG2 cells showed no cytotoxic effect for the concentrations 50 and $100 \mu \mathrm{g} / \mathrm{mL}$ [50].

Table 4: Cytotoxicity towards HepG2 and MCF-7 cell lines of Disopyros kaki leaves aqueous extractlC ${ }_{50}(\mathrm{mg} / \mathrm{mL})$.

\begin{tabular}{|llll|}
\hline Cell line & RojoB & Triumph & Jiro \\
\hline HepG2 & $0.96 \pm 0.05^{\mathrm{a}}$ & $0.98 \pm 0.01^{\mathrm{a}}$ & $1.18 \pm 0.02^{\mathrm{b}}$ \\
\hline MCF7 & $0.85 \pm 0.008^{\mathrm{a}}$ & $0.94 \pm 0.04^{\mathrm{b}}$ & $0.84 \pm 0.001^{\mathrm{a}}$ \\
\hline
\end{tabular}

a, b, Different letters mean significantly different at 0.05

\section{Conclusion}

In this study, bioactive compounds from leaves aqueous extract of three varieties of Diospyros kaki were identified through LC-MS/MS analysis. A total of 29 different phenolic compounds were identified. The obtained extracts showed some biological activities. They exhibited a significant antioxidant effect, a high inhibitory effect for AChE and HMGR and anti-proliferative capacities against MCF7 than HepG2 cell lines. These activities are mainly due to the presence of polyphenols and flavonoids which suggests the potential use of persimmon leaf extract as an alternative medicine. Further studies are needed to understand the anti-proliferative mechanism and to evaluate the effect of these extract on hypercholesterolemia which may be useful in the development of new compounds to treat Alzheimer's disease hyperlipidemia, atherosclerosis, and cancer.

\section{Material And Methods}

\subsection{Chemicals}

All chemicals were of analytical grade. Tris(hydroxymethyl)-aminomethane buffer (Tris; PubChem CID: 6503), sodium nitrite, trifluoroacetic acid, aluminum chloride, sodium carbonate, and milli-Q water $\left(18,2 \mathrm{M} \Omega \cdot \mathrm{cm}\right.$ resistivity at $\left.25^{\circ} \mathrm{C}\right)$ obtained from a $\mathrm{Milli-Q}$ Academic water purification system were obtained from Merk (Darmstadt, Germany).AChE (149 U/mg solid, $241 \mathrm{U} / \mathrm{mg}$ protein), acetylcholine iodine (PubChem CID: 74629), 5,5-dithio-bis-(2-nitrobenzoic acid) (DTNB, PubChem CID: 6254), HMG-CoA reductase kit, 2,2diphenyl-1-picrylhydrazyl (DPPH; PubChem CID: 2735032), gallic acid (PubChem CID: 370), 3-[4,5-dimethylthiazole-2-yl]-2,5diphenyltetrazolium bromide (MTT), dimethyl sulfoxide (DMSO), and Folin-Ciocalteu reagent were purchased from Sigma-Aldrich (Barcelona, Spain).Ethanol ( $\geq$ 99.8\%; PubChem CID: 702) and methanol (PubChem CID: 887) from Riedel-de Haën, formic acid (PubChem CID: 284), water, and acetonitrile (PubChem CID: 6342) HPLC grade were obtained from Termo-Fisher Scientific (Massachusetts, USA).Sodium hydroxide (PubChem CID: 14798) was purchased from José Manuel Gomes dos Santos, Lda (Lisbon, Portugal), and catechin (PubChem CID: 9064) from U.S. Pharmacopeia (Maryland, USA). Trypsin, Dulbecco's modified Eagle medium (DMEM), glutamine, phosphate-buffered saline (PBS), and fetal bovine serum (FBS) were purchased from Lonza.

\subsection{Plant material}

The leaves of an exotic plant (Diospyros kaki L) were picked from orchards located in the north-east and north-west of Tunisia [Beja

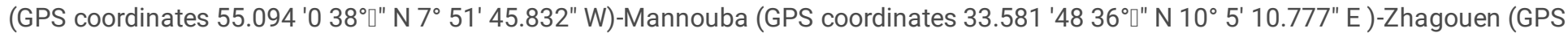

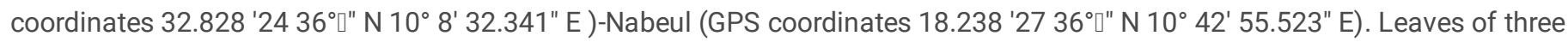
varieties (Triumph, Jiro and Rojo B) were used in this study.The leaves were washed, dried at room temperature, protected from light for seven days and then they were milled into fine powder.

Aqueous plant extracts were prepared as decoctions by using $10 \mathrm{~g}$ of ground dry plant material in $300 \mathrm{~mL}$ of distilled water, boiling for 15 min. The decoctions were filtered through Whatman paper, lyophilized using a HetoPowerDrY LL3300 freeze dryer. The yield of extraction was between 2.5 and $3 \%$.

\subsection{Quantification of total phenols}

Total phenols content was quantified using the Folin-Ciocalteu method, described by Oktay et al., [51]. Each crude extract (20 $\mu$ g) (5 $\mathrm{mg} / \mathrm{mL}$ ) was added to $30 \mu \mathrm{L}$ of the Folin-Ciocalteu reagent and $1350 \mu \mathrm{L}$ of water. The mixture was shaken and after $3 \mathrm{~min}, 90 \mu \mathrm{L}$ of $\mathrm{Na} 2 \mathrm{CO} 3(2 \%)$ was added. The mixture was incubated and shaken for 2 hoursat $4^{\circ} \mathrm{C}$ and the absorbance was measured at $760 \mathrm{~nm}$. The 
total phenolic content was expressed as micrograms of gallic acid equivalents per milligram of extract ( $\mu \mathrm{g}$ of GAE/mg of extract). The assay was performed in triplicate for each extract.

\subsection{Quantification of flavonoids content}

Determination of the flavonoids content was achieved using the method described by Tsai et al., 2007 [52]. To $20 \mu \mathrm{L}$ of sample, 300 $\mu \mathrm{LNaNO}_{2}(5 \%)$ and $480 \mu \mathrm{L}$ of water were added. After standing for $5 \mathrm{~min}, 30 \mu \mathrm{L}$ of $10 \% \mathrm{AlCl}_{3}$.After $1 \mathrm{~min}, 200 \mu \mathrm{L}$ of $\mathrm{NaOH}(1 \mathrm{M})$ was added. The absorbance (A) was measured at $510 \mathrm{~nm}$. Flavonoid content was expressed as micrograms of Catechin equivalent per milligram of extract ( $\mu \mathrm{g}$ of $\mathrm{CE} / \mathrm{mg}$ of extract) per milligram of extract. All assays were performed in triplicate.

\subsection{LC-MS-Qtof analysis}

The identification of the main compounds present in the extract was carried out by LC-MS-Qtof as described by Guedes et al., [29] The suggestion of chemical formulas according to the exact mass was done using the Data Analysis ${ }^{\mathrm{TM}}$ software and Metlin database.

\subsection{Antioxidant activity assays}

The DPPH (1,1-diphenyl-2-picrilhydrazyl) radical scavenging activity of the plant extracts was determined using the method proposed by Katalinic et al. [53]. To $990 \mu \mathrm{L}$ of DPPH $(0.002 \%$ in methanol) solution, $10 \mu \mathrm{L}$ of extract at different concentrations was added. The mixture was shaken vigorously and incubated for $30 \mathrm{~min}$ in the dark at room temperature. The reduction of the DPPH radical was measured by continuously monitoring the decrease in absorption at $517 \mathrm{~nm}$. The antioxidant activity was calculated as:

$A A \%=\left(A_{D P P H}-A_{\text {sample }} / A_{D P P H}\right) * 100$

Where AA is the antioxidant activity, $A_{D P P H}$ is the absorption of the DPPH solution against the blank (methanol), and $A_{\text {sample }}$ is the absorbance of the sample extract against the blank $(990 \mu$ methanol+10 $\mu$ Lextract). Assays were carried out in triplicates and the extract concentration providing $50 \%$ extinction of the $\mathrm{DPPH}$ radical $\left(\mathrm{EC}_{50}\right)$ was obtained by plotting extinction percentage versus extract solution concentration.

\subsection{Acetylcholinesterase inhibition}

Acetylcholinesterase enzymatic activity was measured as described by Falé et al. [54]. A control reaction was carried out using water, which was considered to possess $100 \%$ activity.

$\mathrm{I}(\%)=100-\left(\left(\mathrm{V}_{\text {sample }} / \mathrm{V}_{\text {control }}\right) * 100\right)$

Where $\mathrm{I}$ is the percent inhibition of $\mathrm{AChE}, \mathrm{V}_{\text {sample }}$ is the initial velocity of the extract containing reaction and $\mathrm{V}_{\text {control }}$ is the initial velocity of the control reaction. Assays were carried out in triplicate and a blank with Tris-HCl buffer instead of enzyme solution was used. Extract concentration providing $50 \%$ inhibition (IC50) was obtained plotting the inhibition percentage against extract solution concentrations.

\subsection{HMG-CoA reductase assay}

To determine HMGR activity by HPLC, the enzymatic reaction was performed as suggested by the supplier, with minor modifications. The quantification of nicotinamide adenine dinucleotide phosphate hydrogen (NADPH) was performed by using the method described by Mozzicafreddo et al., [55]. Briefly, aliquots were removed at 0, 1, 2, 4, and 6 min. The reaction was stopped by adding 50\% methanol, and the amount of NADPH was measured by HPLC-DAD [26]. The assays were performed in duplicate. The activity value without inhibitor was considered to be $100 \%$, and the inhibition values were determined by the percentage decrease in activity relative to that without inhibitor.

\subsection{Cytotoxicity assays}

Hep G2 cell lines (ATCC HB-8065, human hepatocellular carcinoma cell line), and MCF7 cell lines (ATCC HTB-22, human mammary gland adenocarcinoma epithelial cell line) were used for cytotoxicity studies. Cells were cultured in DMEM supplemented with $10 \%$ FBS, 100 $\mathrm{U} / \mathrm{ml}$ penicillin, $100 \mathrm{U} / \mathrm{ml}$ streptomycin, and $2 \mathrm{mM} \mathrm{L-glutamine}$ at $37^{\circ} \mathrm{C}$ in an atmosphere with $5 \% \mathrm{CO} 2$. Cells were passed every 48 to 72 $\mathrm{h}$ before reaching confluence [56]. Cytotoxicity studies were performed using the MTT viability [56]. Briefly, the cells were seeded in 96well microplate, using 5000 cells/well, in DMEM supplemented medium and incubated at 37 ॰C in an atmosphere with $5 \%$ CO2 for $48-$ $72 \mathrm{~h}$. When cells reached $80-90 \%$ confluence $(48 \mathrm{~h}$ ). Extracts of persimmon leaves were dissolved in 2\% DMSO+DMEM FBS free with different concentrations ranging from 0.05 to $1 \mathrm{mg} / \mathrm{mL}$. Cells were incubated with the prepared solutions for 24 hat $37^{\circ} \mathrm{C}$ in an 
atmosphere with 5\% CO2before applying the MTT reagent. Untreated cells were considered as a negative control. The assays were done in four replicates for each concentration and the cell viability percentage was calculated by the following formula:

Viability (\%) $=[($ Abs $595-$ Abs 630 of sample) $/($ Abs $595-$ Abs 630 of control) $] \times 100$.

\subsection{Data analysis}

All data are reported as the average \pm SD of three measurements. Additional analysis of variance (ANOVA) with $a=0.05$ (Turkey test) were performed using Origin Pro 2020b.

\section{Abbreviations}

HMG-CoA, 3-hydroxi-3-methyl-glutaril-CoA; DPPH, 2,2-diphenyl-1-picrylhydrazyl; AChE, acetylcholinesterase.

\section{Declarations}

\section{Conflicts of Interest:}

The authors declare no conflict of interest.

\section{Author Contributions:}

Amna Mannai: Methodology, Investigation, Software, Data Curation, Writing (original draft preparation)

Asma Ressaissi: Conceptualization, Methodology, Validation, Software, Review and Editing, supervision

Mossadok Ben-Attia: Conceptualization, Validation, Review and Editing

Maria Luisa Serralheiro: Conceptualization, Validation, Software, Review and Editing, Supervision

Safia El-Bok: Conceptualization, Validation, Review and Editing

\section{Acknowledgements}

This research was supported by the Portuguese Foundation for Science and Technology, FCT, through the Research Unit grant UID/MULTI/04046/2019 to BiolSI and FCT project PTDC/BIA-BQM/28355/2017.

\section{References}

1. Guan, C., Che, Q., Zhang, P., Huang, J., Chachar, S., Ruan, X, ... Yang, Y., Codification and description of growth stages in persimmon (Diospyros kaki Thunb.) using the extended BBCH scale. Scientia Horticulturae, 280, 109895 (2021). https://doi.org/10.1016/j.scienta.2021.109895

2. Xie, C., Xie, Z., Xu, X., Yang, D, Persimmon (Diospyros kaki L.) leaves: A review on traditional uses, phytochemistry and pharmacological properties. Journal of ethnopharmacology, 163, 229-240 (2015). https://doi.org/10.1016/j.jep.2015.01.007

3. Ayşe, K. U. R. T., Ertuğrul, K. A. Y. A., Medical and Cosmetic Applications of Persimmon (Diospyros Kaki): Toxicity Assessment-A review. International Journal of Traditional and Complementary Medicine Research, 1, 162-176 (2020).

4. Soobrattee, M. A., Neergheen, V. S., Luximon-Ramma, A., Aruoma, O. I., Bahorun, T., Phenolics as potential antioxidant therapeutic agents: mechanism and actions. Mutation Research/Fundamental and Molecular mechanisms of mutagenesis, 579, 200213(2005). https://doi.org/10.1016/j.mrfmmm.2005.03.023

5. Lee, J.H., Lee, Y.B., Seo, W.D., Kang, S.T., Lim, J.W. and Cho, K.M, Comparative studies of antioxidant activities and nutritional constituents of persimmon juice (Diospyros kaki L. cv. Gapjubaekmok). Preventive Nutrition and Food Science, 17, 141-151 (2012). https://doi.org/10.3746/pnf.2012.17.2.141

6. Matsumoto, M., Kotani, M., Fujita, A., Higa, S., Kishimoto, T., Suemura, M., Tanaka, T., Oral administration of persimmon leaf extract ameliorates skin symptoms and transepidermal water loss in atopic dermatitis model mice, NC/Nga. British Journal of Dermatology, 146, 221-227 (2002). https://doi.org/10.1046/j.1365-2133.2002.04557.x 
7. Ingkaninan K, Temkitthawon P, Chuenchom K, Yuyaem T, Thongnoi W., Screening for acetylcholinesterase inhibitory activity in plants used in Thai traditional rejuvenating and neurotonic remedies. J Ethnopharmacol, 89, 261-264 (2003). https://doi.org/10.1016/j.jep.2003.08.008

8. Tanaka, T., Higa, S., Hirano, T., Kotani, M., Matsumoto, M., Fujita, A., Kawase, I, Flavonoids as potential anti-allergic substances. Current Medicinal ChemistryAnti-Inflammatory Anti-Allergy Agents, 2, 57-65 (2003). https://doi.org/10.2174/1568014033355790.

9. Sakanaka, S., Tachibana, Y., Okada, Y., Preparation and antioxidant properties ofextracts of Japanese persimmon leaf tea (kakinohacha). Food Chemistry, 89, 569-575 (2005). https://doi.org/10.1016/j.foodchem.2004.03.013

10. Shahat, A. A., Ullah, R., Alqahtani, A. S., Hassanein, H. M., Husseiny, H. A., Mohammed, N. M., Herqash, R. N., Nephroprotective effect of persimmon leaves (Diospyros kaki Lf) against CCl4-induced renal toxicity in Swiss Albino rats. Drug and Chemical Toxicology, 1-9 (2020) https://doi.org/10.1080/01480545.2020.1849269.

11. Esteban-Muñoz, A., Sánchez-Hernández, S., Samaniego-Sánchez, C., Giménez-Martínez, R., Olalla-Herrera, M., Differences in the Phenolic Profile by UPLC Coupled to High Resolution Mass Spectrometry and Antioxidant Capacity of Two Diospyros kaki Varieties. Antioxidants, 10, 31 (2021). https://doi.org/10.3390/antiox10010031

12. Kawakami, K., Shibukura, Y., Kanno, T., Furuki, T., Aketa, S., Hirayama, M., Identification of 2 "-GalloylatedFlavonol 3-0-Glycosides Accumulating in Developing Leaves of Persimmon. Phytochemical Analysis, 22, 403-410 (2011). https://doi.org/10.1002/pca.1295

13. Kotani, M., Matsumoto, M., Fujita, A., Higa, S., Wang, W., Suemura, M., Tanaka, T., Persimmon leaf extract and astragalin inhibit development of dermatitis and IgE elevation in NC/Nga mice. Journal of Allergy and Clinical Immunology, 106, 159-166 (2000). https://doi.org/10.1067/mai.2000.107194

14. Rogerio, A. P., Dora, C. L., Andrade, E. L., Chaves, J. S., Silva, L. F., Lemos-Senna, E., Calixto, J. B., Anti-inflammatory effect of quercetin-loaded microemulsion in the airways allergic inflammatory model in mice. Pharmacological Research, 61, 288-297 (2010). https://doi.org/10.1016/j.phrs.2009.10.005

15. Chen, L. I., Guo, Y., Alsaif, G., Gao, Y. Total Flavonoids Isolated from Diospyros kaki L. f. Leaves Induced Apoptosis and Oxidative Stress in Human Cancer Cells. Anticancer research, 40, 5201-5210 (2020). https://doi.org/10.21873/anticanres.14523.

16. Kim, J. K., Choi, S. J., Cho, H. Y., Hwang, H. J., Kim, Y. J., Lim, S. T., ... Shin, D. H., Protective effects of kaempferol (3, 4', 5, 7tetrahydroxyflavone) against amyloid beta peptide (Aß)-induced neurotoxicity in ICR mice. Bioscience, biotechnology, and biochemistry, 74: 397-401 (2010)._https://doi.org/10.1271/bbb.90585.

17. Anand, P., Singh, B., Singh, N., A review on coumarins as acetylcholinesterase inhibitors for Alzheimer's disease. Bioorganic Med. Chem. 20, 1175-1180 (2012) . https://doi.org/10.1016/j.bmc.2011.12.042

18. Howes MR, Houghton PJ. Plants used in Chinese and Indian traditional medicine for improvement of memory and cognitive function. PharmacolBiochemBehav, 75, 513-527 (2003). https://doi.org/10.1016/S0091-3057(03)00128-X

19. Hernandez, M.F., Falé, P.L. V, Araújo, M.E.M., Serralheiro, M.L.M., Acetylcholinesterase inhibition and antioxidant activity of the water extracts of several Hypericum species. Food Chem. 120, 1076-1082. (2010). https://doi.org/10.1016/j.foodchem.2009.11.055.

20. Fale, P. L. A., Amaral, F., Madeira, P. A., Silva, M. S., Florêncio, M. H., Frazão, F. N., Serralheiro, M. L. M., Acetylcholinesterase inhibition, antioxidant activity and toxicity of Peumusboldus water extracts on HeLa and Caco-2 cell lines. Food and chemicaltoxicology, 50, 2656-2662 (2012). https://doi.org/10.1016/j.fct.2012.04.049.

21. Ressaissi, A., Attia, N., Falé, P.L. V, Pacheco, R., Teixeira, V.H., Aqueous extracts from Nopal (Opuntia ficus-indica): antiacetylcholinesterase and antioxidant activity from phenolic bioactive compounds. Int. J. Green Herb. Chem. 5, 337-348 ( 2016).

22. Röhrl, C., Stangl, H., Cholesterol metabolism-physiological regulation and pathophysiological deregulation by the endoplasmic reticulum. Wiener MedizinischeWochenschrift. 168, 280-285. (2018). https://doi.org/10.1007/s10354-018-0626-2

23. Adaramoye, O. A., Akintayo, O., Achem, J., Fafunso, M. A., Lipid-lowering effects of methanolic extract of Vernonia amygdalina leaves in rats fed on high cholesterol diet. Vascular health and risk management, 4, 235-241 (2008) https://doi.org/10.2147/vhrm.2008.04.01.235

24. Gholamhoseinian, A., Shahouzehi, B., Sharifi-Far, F., Inhibitory activity of some plant methanol extracts on 3-hydroxy-3-methylglutaryl coenzyme a reductase. IJP-International Journal of Pharmacology, 6, 705-711 (2010). https://doi.org/10.3923/ijp.2010.705.711

25. Baskaran, G., Salvamani, S., Ahmad, S. A., Shaharuddin, N. A., Pattiram, P. D., Shukor, M. Y., HMG-CoA reductase inhibitory activity and phytocomponent investigation of Basella alba leaf extract as a treatment for hypercholesterolemia. Drug design, development and therapy, 9, 509 (2015). https://doi.org/10.2147/DDDT.S75056

26. Falé, P.L., Ferreira, C., Maruzzella, F., Helena Florêncio, M., Frazão, F.N., Serralheiro, M.L.M., Evaluation of cholesterol absorption and biosynthesis by decoctions of Annona cherimola leaves. J. Ethnopharmacol. 150, 718-723 (2013).

Page $10 / 15$ 
https://doi.org/10.1016/j.jep.2013.09.029

27. Arantes, A.A., Falé, P.L., Costa, L.C.B., Pacheco, R., Ascensão, L., Serralheiro, M.L., Inhibition of HMG-CoA reductase activity and cholesterol permeation through Caco-2 cells by caffeoylquinic acids from Vernonia condensata leaves. Rev. Bras. Farmacogn. 26, 738-743 (2016) https://doi.org/10.1016/j.bjp.2016.05.008

28. Ressaissi, A., Attia, N., Falé, P.L., Pacheco, R., Victor, B.L., Machuqueiro, M., Serralheiro, M.L.M., Isorhamnetin derivatives and piscidic acid for hypercholesterolemia: cholesterol permeability , HMG-CoA reductase inhibition, and docking studies. Arch. Pharm. Res. 40, 1278-1286 (2017). https://doi.org/10.1007/s12272-017-0959-1

29. Guedes, L., Reis, P.B.P.S., Machuqueiro, M., Ressaissi, A., Pacheco, R., Serralheiro, M.L.,. Bioactivities of Centaurium erythraea (Gentianaceae) Decoctions: Antioxidant activity, enzyme inhibition and docking studies. Molecules. 24, 37-95 (2019). https://doi.org/10.3390/molecules.24203795

30. Fadel, S. R., Bendif, H., Guedes, L., André, R., Pacheco, R., Guedes, R., ... Serralheiro, M. L., Bioactivities of iridoids and flavonoids present in decoctions from aerial parts of Verbascum betonicifolium. European Journal of Integrative Medicine, 37, 101-171 (2020). https://doi.org/10.1016/j.eujim.2020.101171

31. Ebrahimi, A., Schluesener, H., Natural polyphenols against neurodegenerative disorders: Potentials and pitfalls. Ageing Res. Rev. 11, 329-345 (2012). https://doi.org/10.1016/j.arr.2012.01.006

32. Siti, H.N., Kamisah, Y., Kamsiah, J., The role of oxidative stress, antioxidants and vascular inflammation in cardiovascular disease (a review). Vasc. Pharmacol. 71, 40-56 (2015). https://doi.org/10.1016/j.vph.2015.03.005

33. Mileo, A. M., Miccadei, S., Polyphenols as modulator of oxidative stress in cancer disease: new therapeutic strategies. Oxidative medicine and cellular longevity, (2016). https://doi.org/10.1155/2016/6475624

34. Kurgan, N., Tsakiridis, E., Kouvelioti, R., Moore, J., Klentrou, P., Tsiani, E., Inhibition of human lung cancer cell proliferation and survival by post-exercise serum is associated with the inhibition of Akt, mTOR, p70 S6K, and Erk1/2. Cancers. 9, 46 (2017). https://doi.org/10.3390/cancers9050046

35. Liu, J. R., Dong, H. W., Chen, B. Q., Zhao, P., Liu, R. H., Fresh apples suppress mammary carcinogenesis and proliferative activity and induce apoptosis in mammary tumors of the Sprague Dawley rat. Journal of agricultural and food chemistry, 57, 297-304 (2009). https://doi.org/10.1021/jf801826w

36. Sun, L., Zhang, J., Lu, X., Zhang, L., Zhang, Y., Evaluation to the antioxidant activity of total flavonoids extract from persimmon (Diospyros kaki L.) leaves. Food and chemical toxicology, 49, 2689-2696 (2011) https://doi.org/10.1016/j.fct.2011.07.020

37. Veberic, R., Jurhar, J., Mikulic-Petkovsek, M., Stampar, F., Schmitzer, V., Comparative study of primary and secondary metabolites in 11 cultivars of persimmon fruit (Diospyros kaki L.). Food Chemistry, 119, 477-483 (2010). https://doi.org/10.1016/j.cub.2017.05.064

38. Akagi, T., Katayama-lkegami, A., Yonemori, K., Proanthocyanidin biosynthesis of persimmon (Diospyros kaki Thunb.) fruit. Scientia Horticulturae, 130, 373-380 (2011). https://doi.org/10.1016/j.scienta.2011.07.021

39. Martínez-Las Heras, R., Quifer-Rada, P., Andrés, A., Lamuela-Raventós, R., Polyphenolic profile of persimmon leaves by high resolution mass spectrometry (LC-ESI-LTQ-Orbitrap-MS). Journal of Functional Foods, 23, 370-377 (2016). https://doi.org/10.1016/j.jff.2016.02.048

40. Pisoschi, A.M., Pop, A.,. The role of antioxidants in the chemistry of oxidative stress: A review. Eur. J. Med. Chem. 97, 55-74 (2015). https://doi.org/10.1016/j.ejmech.2015.04.040

41. Khadhri, A., Bouali, I., Belkhir, S., Mokded, R., Smiti, S., Falé, P.,... Serralheiro, M. L. M., In vitro digestion, antioxidant and antiacetylcholinesterase activities of two species of Ruta: Rutachalepensis and Rutamontana. Pharmaceutical biology, 55, 101-107 (2017). https://doi.org/10.1080/13880209.2016.1230634

42. Maisuthisakul, P., Pasuk, S., Ritthiruangdej, P., Relationship between antioxidant properties and chemical composition of some Thai plants. Journal of Food Composition and Analysis, 21, 229-240 (2008). https://doi.org/10.1016/j.jfca.2007.11.005

43. Yokozawa,T., Chen, C. P., Dong, E., Tanaka, T., Nonaka, G.I., Nishioka, I., Study on the inhibitory effect of tannins and flavonoids against the 1,1-diphenyl-2 picrylhydrazyl radical. Biochem. Pharmacol. 56, 213-222 (1998). https://doi.org/10.1016/S00062952(98)00128-2

44. Okawa, M., Kinjo, J., Nohara, T., Ono, M.,. DPPH (1,1-diphenyl-2-picrylhydrazyl) radical scavenging activity of flavonoids obtained from some medicinal plants. Biol. Pharm. Bull. 24, 1202-1205 (2001) https://doi.org/10.1248/bpb.24.1202

45. Williams, R.J., Spencer, J.P., Rice-Evans, C., Flavonoids: Antioxidants or signalling molecules?. Free. Radic. Biol. Med. 36, 838-849 (2004). https://doi.org/10.1016/j.freeradbiomed.2004.01.001

Page 11/15 
46. Kim, Y. J., Lim, H. S., Kim, J. H., Na, M., Jeong, S. J., Quantitative analysis of 7 compounds in Diospyros lotus leaf extract and its biological effects on neuroprotection and antineuroinflammation. Natural Product Communications, 15. 1934578-20924859 (2020). https://doi.org/10.1177/1934578X.20924859

47. Hwang, K. A., Hwang, Y. J., Hwang, I. G., Song, J., Cho, S. M., Cholesterol-lowering effect of astringent persimmon fruits (Diospyros kaki Thunb.) extracts. Food science and biotechnology, 26, 229-235 (2017). https://doi.org/10.1007/s10068-017-0031-4

48. Ressaissi, A., Pacheco, R., Serralheiro, M.L.M., Molecular-level changes induced by hydroxycinnamic acid derivatives in HepG2 cell line: Comparison with pravastatin. Life Sci. 283, 119846 (2021). https://doi.org/10.1016/j.Ifs.2021.119846

49. Okonogi, S., Duangrat, C., Anuchpreeda, S., Tachakittirungrod, S., Chowwanapoonpohn, S., Comparison of antioxidant capacities and cytotoxicities of certain fruit peels. Food chemistry, 103, 839-846 (2007). https://doi.org/10.1016/j.foodchem.2006.09.034

50. Hwang, K. A., Hwang, Y. J., Hwang, I. G., Song, J., Cho, S. M., Cholesterol-lowering effect of astringent persimmon fruits (Diospyros kaki Thunb.) extracts. Food science and biotechnology, 26(1), 229-235 (2017). https://doi.org/D0I 10.1007/s10068-017.0031.4

51. Oktay, M., Gulcin, I., Kufrevioglu, O.I., Determination of in vitro antioxidant activity of fennel (foeniculum vulgare) seed extracts. LWT Food. Sci. Technol. 36, 263-271 (2003). https://doi.org/10.1016/S0023-6438(02)00226-8

52. Tsai, P.J., Tsai, T.H., Ho, S.C., In vitro inhibitory effects of rosemary extracts on growth and glucosyltransferase activity of Streptococcus sobrinus. Food Chemistry, 105, 311-316 (2007). https://doi.org/10.1016/j.foodchem.2006.11.051

53. Katalinic, V., Milos, M., Kulisic, T., Jukic, M., Screening of 70 medicinal plant extracts for antioxidant capacity and total phenols. Food Chem. 94, 550-557 (2006). https://doi.org/10.1016/j.foodchem.2004.12.004

54. Fale, P. L. A., Amaral, F., Madeira, P. A., Silva, M. S., Florêncio, M. H., Frazão, F. N., Serralheiro, M. L. M., Acetylcholinesterase inhibition, antioxidant activity and toxicity of Peumusboldus water extracts on HeLa and Caco-2 cell lines. Food and chemicaltoxicology, 50, 2656-2662 (2012) https://doi.org/10.1016/j.fct.2012.04.049

55. Mozzicafreddo M, Cuccioloni M, Eleuteri AM, Angeletti M., Rapid reverse phase-HPLC assay of HMG-CoA reductase activity. J LipidRes, 51, 2460-2463 (2010). https://doi.org/10.1194/jlr.D006155

56. Pham, D. C., Nguyen, H. C., Nguyen, T. H. L., Ho, H. L., Trinh, T. K., Riyaphan, J., Weng, C. F. Optimization of Ultrasound-Assisted Extraction of Flavonoids from Celastrushindsii Leaves Using Response Surface Methodology and Evaluation of Their Antioxidant and Antitumor Activities. BioMed research international, 3497107 (2020) https://doi.org/10.1155/2020/3497107

57. https://metlin.scripps.edu/landing_page.php?pgcontent=mainPage.

\section{Figures}



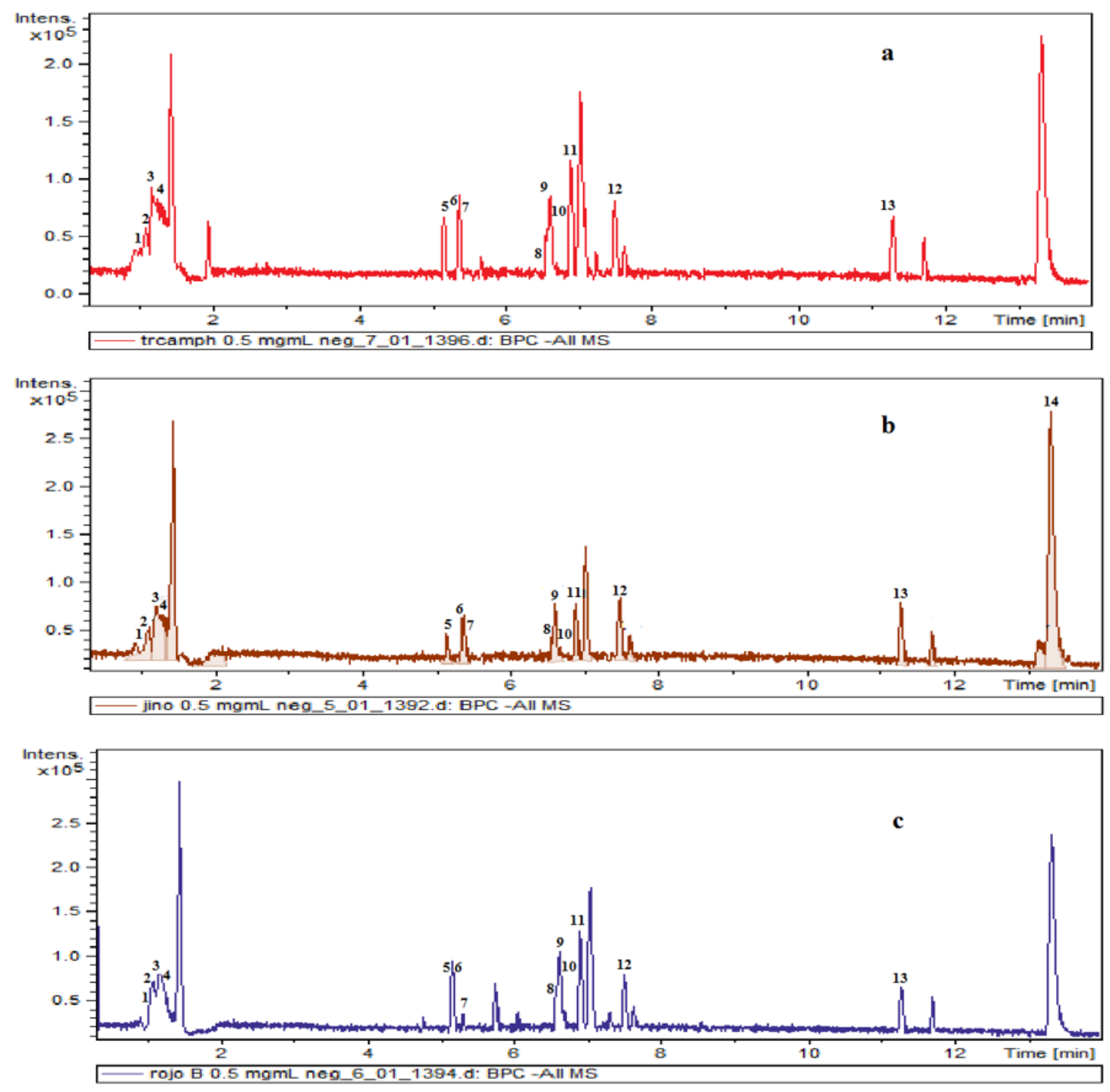

\section{Figure 1}

Chromatogram of persimmon by LC-MS-Qtof in the negative ion mode for Triumph (a), Jiro (b) and Rojo B (c) varieties. 


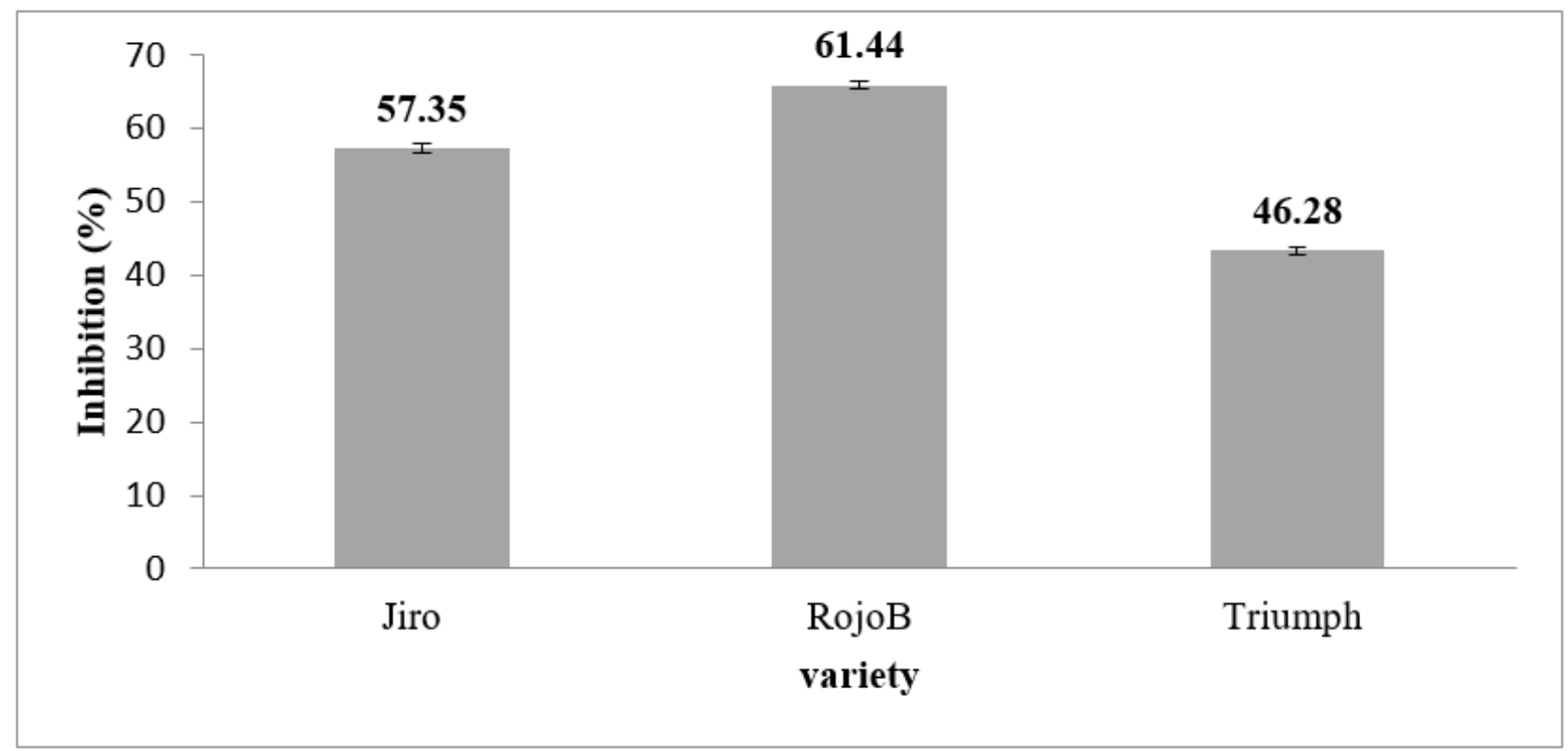

\section{Figure 2}

Inhibition (\%) of HMG-CoA reductase for $100 \mu \mathrm{g} / \mathrm{mL}$ of Persimmon leaves extracts 


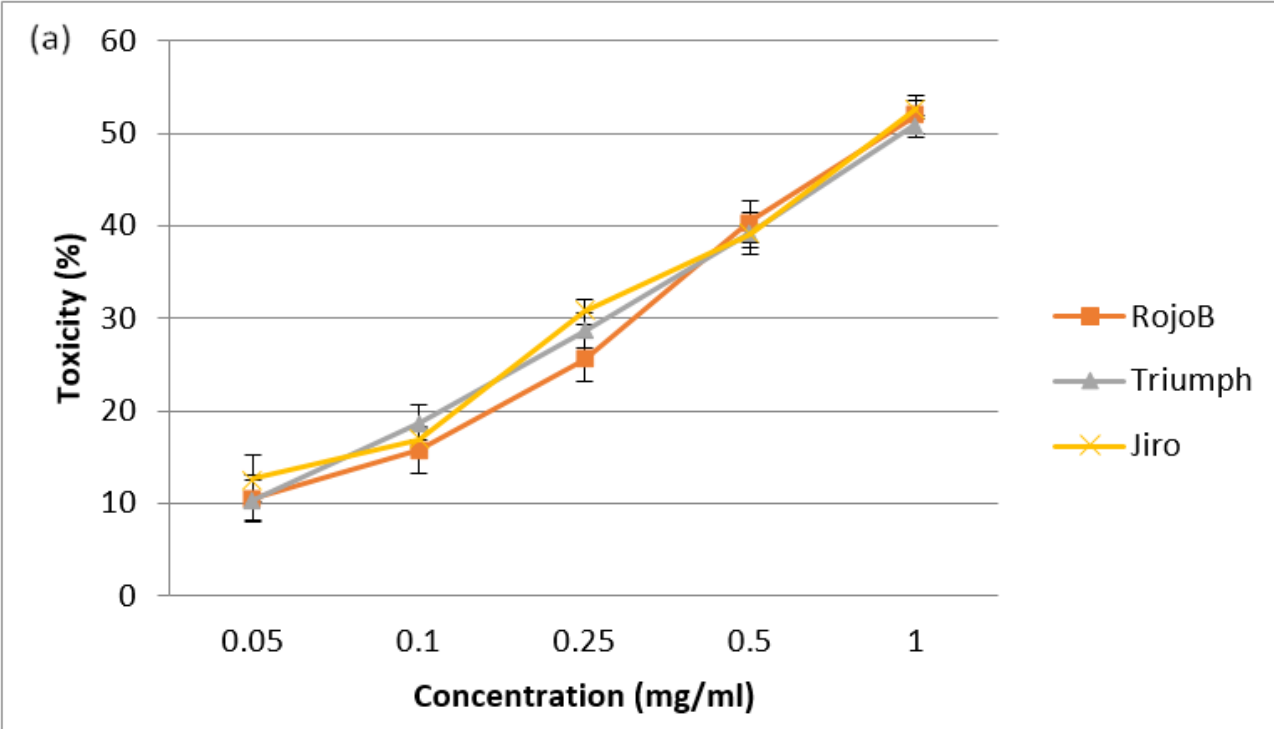

(b)

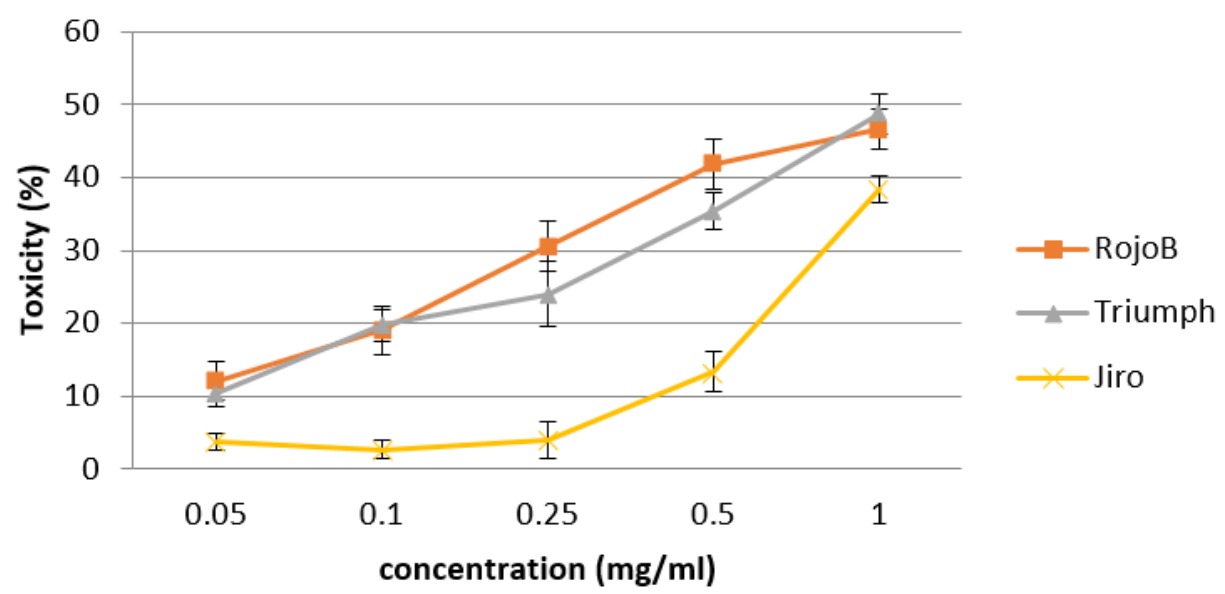

\section{Figure 3}

Cytotoxicity of the extracts toward two cell lines: (a) MCF-7cell lines, (b) HepG2cell lines. 